УДК 316.4:338

https://doi.org/10.33296/2707-0654-7(14)-09

http://orcid.org/0000-0003-2616-9499

\title{
Ганна МИХАЛЬЧЕНКО
}

доктор економічних наук, доцент, завідувач кафедри економіки підприємств i менеджменту, Навчально-науковий професійно-педагогічний інститут Української інженерно-педагогічної академії, м. Бахмут, Україна

\section{ЗАБЕЗПЕЧЕННЯ СОЦАЛЬНОЇ БЕЗПЕКИ НАСЕЛЕННЯ В УМОВАХ ЗАГОСТРЕННЯ СОЦІАЛЬНО-ЕКОНОМІЧНИХ РИЗИКІВ}

Анотація. В статті доведено необхідність забезпечення соціальної безпеки для населення, яка $є$ важливим фактором соціальної стабільності країни та іiї національної безпеки, враховуючи посилення соціальноекономічних ризиків, зростання соціальної напруги у суспільстві та незадовільний соціально-економічний розвиток країни. Автором охарактеризовано основні соціально-економічні ризики, 3 якими стикається населення країни у сучасних умовах та які призводять до високої залежності забезпечення добробуту значної частини населення від соціального забезпечення та соціального захисту.

Метою статті $\epsilon$ дослідження сучасних тенденцій соціальноекономічного стану країни та визначення його особливостей в умовах соціально-економічної та політичної нестабільності.

Автором проаналізовано чинне законодавство країни та сучасні підходи до визначення поняття «соціальна безпека», зроблено висновок, що економічна складова $\epsilon$ однією 3 найважливіших складових соціальної безпеки. Доведено, що соціальна безпека в значній мірі залежить від економічних і соціальних факторів. Відповідно до цього охарактеризовано основні демографічні, економічні та соціальні показники соціальноекономічного стану країни; зроблено висновок про недотримання умов соціальної безпеки для населення країни, що проявляється у погіршенні демографічної ситуації в країні, значному майновому розшаруванні суспільства, поширенні бідності, невідповідності соціальних гарантій для забезпечення гідного рівня життя тощо. Відзначено, що рівень добробуту населення залишається надзвичайно низьким, виходячи з аналізу основних його показників. 
На основі окреслених проблем та проведеного дослідження автором визначено напрями забезпечення соціальної безпеки населення країни для підвищення рівня життя населення, стимулювання його економічної активності та зайнятості, що дозволить покращити соціально-економічний стан країни та зменшити негативні наслідки існуючих соціальноекономічних ризиків.

Ключові слова: соціальна безпека, населення, соціально-економічні ризики, бідність, добробут, мінімальна заробітна плата, прожитковий мінімум.

Вступ. В умовах загострення соціально-економічних проблем, розшарування суспільства, поширення бідності серед населення, з одного боку, та збільшення вимог до дотримання гідного рівня життя населення відповідно до Цілей Сталого Розвитку [1], з іншого боку, в Україні посилюється нагальна потреба щодо забезпечення певного рівня соціальної безпеки, яка є важливим фактором соціальної стабільності країни та ії̈ національної безпеки. На жаль, сучасний етап розвитку держави знаходиться на рівні, що передбачає високу залежність забезпечення добробуту значної частини населення від соціального забезпечення та соціального захисту.

Аналіз останніх досліджень і публікацій. Необхідність соціального захисту досліджується вітчизняними науковцями вже довгий час, серед яких найбільш суттєві здобутки належать О. Амоші, М. Білинській, В. Бодрову. Б. Данилишину, Т. Заяць та іншим. Проблеми ж забезпечення соціальної безпеки почали розглядатися відносно недавно, але на цей час вітчизняна наука вже має численні здобутки таких дослідників як А. Колот, В. Куйбіда, Е. Лібанова [7], О. Новікова [9], П. Шевчук [18] тощо. Але до цього часу наша країна не вирішила в повному обсязі проблему забезпечення соціальної безпеки свого населення шляхом дотримання обов'язків держави щодо забезпечення гідного життя людини.

Формулювання цілей статті. Провести дослідження сучасних тенденцій соціально-економічного стану країни, виокремити його особливості 
в умовах соціально-економічної та політичної нестабільності. На основі окреслених проблем визначити напрями забезпечення соціальної безпеки населення країни як важливого чинника покращання доброту та якості життя як пересічних громадян, так і фактора покращання соціально-економічного стану країни в цілому, їі національної безпеки зокрема.

Виклад основного матеріалу. Не дивлячись на безперервний процес реформування всіх гілок влади та устрою держави, населення продовжує потерпати від численної кількості соціально-економічних ризиків, серед яких можна назвати погіршення демографічної ситуації, поширення безробіття, відсутність робочих місць як в селах, так і в невеликих містах, міграційний відтік, підвищення вартості життя, недосконала медична допомога, проблеми категорії внутрішньо переміщених осіб, невирішеність ситуації на Сході країни. Все це відбувається на тлі занепаду економіки країни, збільшення державного боргу, посилення криміногенного та психологічного фактору в поведінці великої кількості людей, що пройшли через АТО та ООС, що додатково поглиблює вище зазначені ризики соціальної безпеки в країні. У зв’язку з цим, все більша частина населення не може обійтися без державної підтримки, а аналіз ситуації з державним бюджетом щодо соціальних питань свідчить про скорочення можливостей надавати населенню соціальну підтримку в достатньому обсязі. Так, кількість родин, яким призначено субсидії у січнілютому у 2019 року в 1,7 рази перевищувала показники даного періоду 2018 року. Загалом субсидії на оплату житлово-комунальних послуг у лютому 2019 року отримували 3 млн. 736 тисяч родин, що складає майже чверть від усієї кількості домогосподарств в Україні [10]. Тобто, лише за цією характеристикою майже чверть населення не може себе забезпечити самостійно та вимагає підтримки держави.

Загалом, у 2019 році на виплату субсидій з державного бюджету 
було виділено 55,1 млрд. гривень. У 2020 році на субсидії з державного бюджету заплановано виділити 47,62 мільярда гривень, що на 13,56\% менше від видатків державного бюджету у попередньому році [15]. Необхідно відзначити, що таке скорочення пояснюється Урядом не зменшенням кількості осіб, що потребують допомоги, а обмеженою фінансовою спроможністю та незадовільною економічною ситуацією в країні.

На жаль, сьогодні склалася ситуація, коли навіть працююча людина не завжди може бути самодостатньою щодо подолання існуючих соціально-економічних ризиків. Особливо потерпає молодь, яка повинна отримати той соціально-економічний трамплін, що дозволить їй ефективно працювати для власного забезпечення та забезпечення добробуту своїх родин, ефективного розвитку економіки та зниження соціального навантаження в майбутньому.

Загостренню соціально-економічних ризиків сприяє і посилення демографічних деформацій, які посилюють проблеми пенсійного забезпечення, враховуючи, що більшість заробітчан не здійснюють внесків до Пенсійного фонду, а повертаючись на старість в Україну також претендують на отримання пенсії. Уже в 2010 році виникла демографічна яма, яка погіршується всі ці роки. За даними Світового банку Україна знаходиться в першій 20-ці країн з вимираючим населенням. Найстрашніше для економічного розвитку країни $€$ те, що в останнє десятиріччя скорочується населення працездатного віку. Сьогодні Україна за часткою населення віком понад 60 років входить у тридцятку найстаріших держав, займаючи 25-26 місце у рейтингу країн світу за цим показником [14]. Отже, сучасна депопуляція населення, за демографічним прогнозом фахівців, вже через 4-5 років призведе до скорочення трудових ресурсів на 7 млн. осіб, що може мати катастрофічний вплив на процеси розвитку суспільства та 
соціальну безпеку країни.

Зростання соціальної напруги у суспільстві, стримує та дестабілізує соціально-економічний розвиток країни [8]. Україна залишається однією 3 найбідніших держав у світі за рівнем життя та посідає 7 місце в міжнародному рейтингу бідності країн, близько 60\% українців живуть за межею бідності, а за рейтингом рівня щастя населення перебуває на 132 місці серед 155 країн світу [16]. При цьому в Україні спостерігається значна розбіжність між бідними та багатими. Середня заробітна плата 1-го \% найбільш високооплачуваних українських працівників перевищує середній заробіток 50\% найменш оплачуваних працівників більше ніж у 40 разів, в той час як цей показник у скандинавських країнах дорівнює 7,1, європейських країнах - 11,7, у США - 24 рази. Співвідношення в посадових окладах між працівником основної професії та керівником на окремих підприємствах досягає 1:200. За цих умов, нагальною необхідністю стає забезпечення соціальної безпеки для всіх верст населення країни.

Відповідно чинного законодавства країни, заходи щодо забезпечення соціальних гарантій 3 боку держави мають гарантувати кожному громадянинові певний рівень благ і послуг, як за рахунок самого громадянина, так і за рахунок перерозподілу ресурсів між населенням на цілі його матеріального забезпечення. Але окремого нормативного акту, що розглядає соціальну безпеку в Україні немає. Так, Декларація про державний суверенітет України розглядає економічну самостійність, екологічну безпеку, зовнішню і внутрішню безпеку, але не визначає соціальну безпеку [2]. Конституція України також не містить трактування цього поняття, а розглядає національну, економічну, інформаційну та екологічну безпеку. Лише Стаття 46 присвячена трактуванню поняття соціальний захист громадян, «що включає право на забезпечення їх у разі 
повної, часткової або тимчасової втрати працездатності, втрати годувальника, безробіття з незалежних від них обставин, а також у старості та в інших випадках, передбачених законом» [6].

Закон України «Про основи національної безпеки України» визначає загальне поняття безпеки як «захищеність життєво важливих інтересів людини і громадянина, суспільства i держави, за якої забезпечується сталий розвиток суспільства, своєчасне виявлення, запобігання, нейтралізація реальних і потенційних загроз національним інтересам» [4].

На думку дослідників, соціальна безпека є складовою національної безпеки, яка розглядає стан захищеності населення щодо загрози соціальним інтересам. В свою чергу, стан захищеності $\epsilon$ результатом реалізації політики соціального захисту [7] або характеризує стан захищеності соціальних інтересів особи і суспільства від впливу загроз національній безпеці, що $є$ наслідком реалізації заходів соціального захисту, який характеризує їх результативність та ефективність [9].

Враховуючи вище зазначені соціально-економічні ризики, від яких потерпає населення нашої країни, нам здається більш вичерпним визначення П. Шевчука, який розглядає соціальну безпеку як стан життєдіяльності, забезпечений комплексом організаційно-правових та економічних заходів, спрямованих на реалізацію соціальних інтересів, формування сприятливої демографічної ситуації, збереження генофонду держави i трансформацію трудових ресурсів відповідно до ринкових вимог [18].

Отже, економічна складова $є$ однією 3 найважливіших складових соціальної безпеки, бо саме від неї залежить як добробут окремої людини, так і загальне економічна ситуація в країні. Звертаючи увагу на економічні фактори, необхідно відзначити, що за даними Державної служби статистики, валовий внутрішній продукт (ВВП) України у 2012-2018 роках 
підвищився 3 1,4 трлн. грн. у 2012 році до 3,56 трлн. грн. у 2018 році (табл. 1.).

Таблиця 1

Динаміка ВВП України за 2012-2018 роки

\begin{tabular}{|c|c|c|c|c|c|}
\hline \multirow[t]{2}{*}{ Рік } & \multirow{2}{*}{$\begin{array}{c}\text { Розмір ВВП, } \\
\text { млн. грн }\end{array}$} & \multicolumn{2}{|c|}{$\begin{array}{c}\text { Відношення до } \\
\text { показника минулого } \\
\text { року }\end{array}$} & \multirow{2}{*}{$\begin{array}{c}\text { Розмір ВВП на } \\
\text { душу населення, } \\
\text { грн. }\end{array}$} & \multirow{2}{*}{$\begin{array}{c}\text { Абсолютне } \\
\text { відношення до } \\
\text { показника минулого } \\
\text { року, грн. }\end{array}$} \\
\hline & & $\begin{array}{c}\text { абсолютне, } \\
\text { млн. грн. }\end{array}$ & $\begin{array}{c}\text { відносне, } \\
\%\end{array}$ & & \\
\hline 2012 & 1408889 & 92289 & $+7,0$ & 30929 & 2077 \\
\hline 2013 & 1454931 & 46042 & $+3,3$ & 32029 & 1099,9 \\
\hline 2014* & 1566728 & 111797 & $+7,7$ & 34627 & 2598 \\
\hline $2015^{*}$ & 1979458 & 412730 & $+26,3$ & 46291 & 11664 \\
\hline $2016^{*}$ & 2383182 & 403724 & $+20,4$ & 55854 & 9643 \\
\hline $2017 *$ & 2982920 & 599738 & $+25.2 \%$ & 70224 & 14370 \\
\hline $2018^{*}$ & 3558706 & 575786 & $+19.3 \%$ & 84192 & 13968 \\
\hline
\end{tabular}

*Без урахування тимчасово окупованої території Автономної Республіки Крим і м. Севастополя та частини зони проведення АТО.

У 2018 році в Україні номінальний ВВП склав 3558,7 млрд. грн [11]. Внаслідок зростання обсягів ВВП, зростав показник розміру ВВП на душу населення, але враховуючи той факт, що розміри ВВП постійно збільшувалися, а чисельність населення зменшувалася, розмір ВВП на душу населення зростав більш швидкими темпами ніж обсяги самого ВВП.

Нацбанк України наприкінці січня 2019 року погіршив оцінку зростання ВВП України минулого року з 3,4\% до 3,3\%, оцінюючи його в четвертому кварталі в 3,3\%. Згідно 3 його очікуваннями, цього року економіка країни збільшиться на 2,5\%, а у 2020-му - на 2,9\%.

Згідно 3 консенсус-прогнозом, складеним Мінекономрозвитку, зростання ВВП України в 2018 році оцінювалося на рівні 3,1\%, у 2019 році-2,9\%.

Необхідно зазначити, що соціальний захист населення в значній мірі обумовлюється економічними і соціальними факторами, які знаходяться під впливом розвитку ринку праці. Ринок зайнятості є складовою частиною економічної системи країни, адже він відображає більшість політичних та 
соціально-економічних процесів, що відбуваються в державі. Досягнення високого рівня зайнятості - одна 3 основних цілей макроекономічної політики держави. Загально відомо, що нижчий рівень безробіття обумовлює і зниження рівня бідності в країні. У 2018 році порівняно 3 2017-м: кількість зайнятого населення України у віці 15-70 років зросла на 204,5 тис. осіб та досягла 16,4 млн. осіб; рівень зайнятості населення України у віці $15-70$ років зріс із $56,1 \%$ до $57,1 \%$ населення відповідного віку (рис. 1) [12].

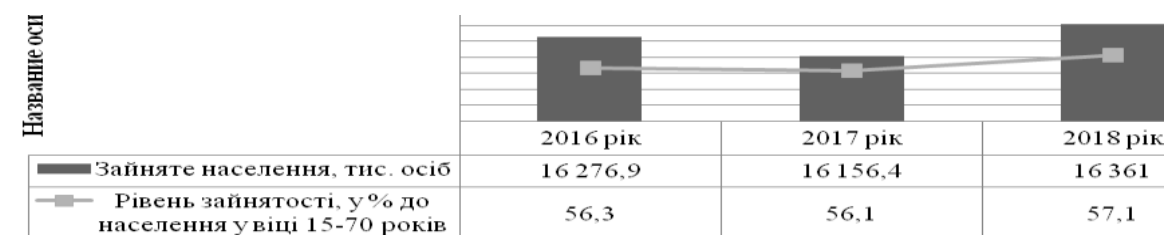

Рис. 1. Зайнятість населення у 2016-2018 роках

Зростання рівня зайнятості відбулося в усіх регіонах України, найбільш суттєво у Луганській (з 54,7\% до 56,9\%), Рівненській ( 3 55,1\% до $56,8 \%$ ), Тернопільській (з 51,0\% до 52,7\%), Вінницькій (з 55,3\% до 56,8\%) та Запорізькій (з 55,2\% до 56,7\%) областях. Кількість безробітного населення у 2018 р. за методологією МОП у віці 15-70 років зменшилась на 119,4 тис. осіб до 1,6 млн. осіб; рівень безробіття населення у віці 15-70 років знизився 3 9,5\% до $8,8 \%$ економічно активного населення відповідного віку.

Слід зазначити, що саме відсутність постійного місця роботи, труднощі з працевлаштуванням у найближчий перспективі, невдоволення власним матеріальним становищем та добробутом своєї родини, невисока заробітна плата обумовлюють необхідність соціального захисту населення.

Серед економічних умов ефективного функціонування ринку праці одним 3 найважливіших факторів соціально-трудових відносин $є$ рівень заробітної плати штатних працівників. 31 січня 2019 року підвищено 
мінімальну заробітну плату до 4173 гривень (що перевищує прожитковий мінімум для працездатних осіб удвічі). 31 січня 2019 року, відповідно до бюджету на 2019 рік, прожитковий мінімум на одну особу в розрахунку на місяць складає 1853 гривні [5]. Але фізіологічний та функціональний аналіз забезпечення мінімальний потреб людини свідчить, що прожитковий міеімум навіть для працюючої людини занижено в 2,5 рази, а тому приявязка мінімальної заробітної плати та пенсій до прожиткового мінімуму призводить до того, що в Україні до цього часу середній рівень добробуту населення залишається надзвичайно низьким, виходячи 3 аналізу основних його показників. Частка населення із середньодушовими еквівалентними загальними доходами у місяць, нижчими законодавчо встановленого прожиткового мінімуму, зросла в порівнянні з минулим роком. На жаль, позитивна динаміка номінальної заробітної плати, яка в 2017 році зросла на 37,1\%, а у 2018 році - на 24,8\% (у порівнянні 3 попереднім роком), не змогла забезпечити суттєвого покращання якості життя працюючого населення, хоча за офіційними даними протягом 2018 року спостерігалася позитивна динаміка щодо зростання доходів населення. Номінальні доходи населення збільшилися на 21,4\% порівняно з 2017 роком (рис. 2.) [5, 11].

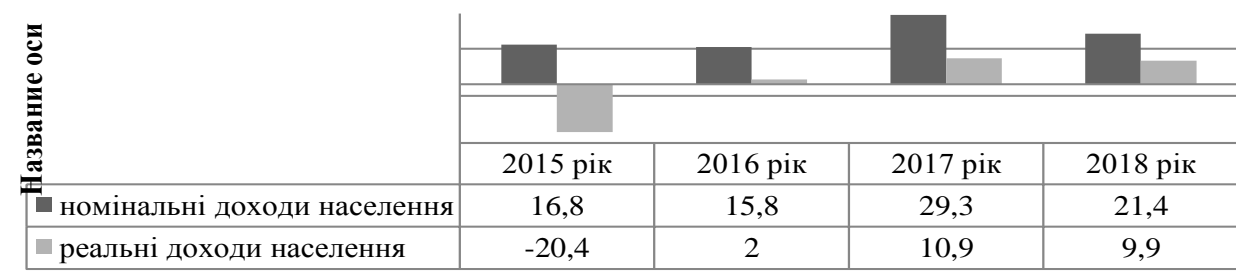

Рис. 2. Динаміка номінальних і реальних доходів населення ( $\% \%$ до попереднього року)

Наявний дохід, який може бути використаний населенням на придбання товарів та послуг, збільшився на 21,9\%, а реальний наявний, визначений з урахуванням цінового фактору, - на 9,9 відсотка. 
Наявний дохід у розрахунку на одну особу у 2018 році становив 57 908,6 грн., що на 10 638,9 грн. більше, ніж у 2017 році. В цілому за 2018 рік розмір прожиткового мінімуму (грудень 2018 року до грудня 2017 року) підвищився на 9 відсотків. За офіційними статистичними даними в Україні розмір місячного прожиткового мінімуму збільшується (рис. 3).

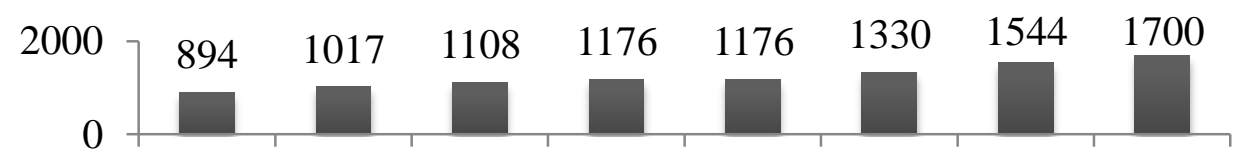

2011 p. 2012 p. 2013 p. 2014 p. 2015 p. 2016 p. 2017 p. 2018 p.

Рис. 3. Динаміка рівня прожиткового мінімуму в Україні в 2011-2018 pр., (на 1 січня кожного року), грн.

Так, за останні вісім років розмір прожиткового мінімуму на одну особу мав тенденцію до зростання. Розмір прожиткового мінімуму зростав 3 кожним роком в середньому на 9,7\% або на 115,14 грн. [13].

Найбільше підвищення прожиткового мінімуму спостерігалося у 2017 p. - на 214 грн. або на 16,09\% у порівнянні з 2016 р. У 2018 р. даний показник зріс аж на 806 грн. або на 90,1\% порівняно з 2011 р. Також слід відмітити, що у період 2014-2015 рр. прожитковий мінімум взагалі не змінювався і становив 1176 грн.

Міністерство соціальної політики України повідомляє, що фактичний розмір прожиткового мінімуму у цінах серпня 2018 р. в розрахунку на місяць на одну особу становив 3215 грн. Виходить, що «узаконений» прожитковий мінімум менше фактичного майже у 2,5 рази.

У 2018 році також спостерігалась позитивна динаміка щодо зростання заробітної плати. Середньомісячна заробітна плата у 2018 році порівняно 3 2017 роком зросла на 24,8\% і становила 8865 грн., реальна заробітна плата зросла на 12,5\%. Відповідно до підвищення прожиткового мінімуму підвищено також розміри державної соціальної допомоги та інших соціальних виплат.

Серйозною проблемою залишається поглиблення нерівності в оплаті 
праці в різних видах економічної діяльності та регіонах, між підприємствами та в межах одного підприємства. Ситуація з нерівністю в оплаті праці на госпрозрахункових підприємствах значно гірша. При поширенні тенденції до зрівнялівки в оплаті кваліфікованої та некваліфікованої праці заробітна плата керівників деяких державних підприємств перевищує заробітну плату працівників основного виробництва у 200 разів. Поряд 3 цим відбувається нівелювання ставлення до рівня освіти, коли людина з вищою або спеціальною освітою може отримувати мінімальну заробітну плату, як і особа без освіти.

У 2016 році найбільша частка населення (32,4\%) мали середньо душовий дохід населення в діапазоні від 1560,1 до 2280 грн. в місяць. Зросла частка домогосподарств із середньодушовими еквівалентними загальними доходами від 1920 до понад 3720 грн. в місяць. У 2018 році вже 29\% населення мало дохід понад 5160 грн. в місяць [11].

Погіршення економічної ситуації призводить до зниження розміру заробітної плати, зростання заборгованостей із іiі виплати, зростання утриманців за рахунок звільнених та безробітних тощо, що веде до зниження рівня доходів населення, його розшарування та зростання частки бідних, а отже населення потребує соціальної підтримки 3 боку держави. Для забезпечення соціальної безпеки суспільства в умовах загострення соціальноекономічних викликів необхідно вирішити комплекс наступних заходів:

- забезпечити умови для трансформації державної політики доходів, яка забезпечить підвищення рівня життя населення;

- розробити заходи щодо усунення причин глибокого розшарування суспільства, яке призвело до значних деформацій соціальної структури, поширення бідності;

- мінімізувати наслідки поляризації доходів та соціального розшарування населення за рахунок введення економічно та політично обгрунтовано податку на розкіш, прогресивної системи оподаткування 
прибутків; удосконалити взаємодію ринкових i державних важелів, спрямованих на формування дієздатної та ефективної соціальної політики;

- сформувати умови для збільшення «середнього класу», легалізації ринку зайнятості, бо сьогоднішня тінізація оплати праці не тільки призводить до недоотримання податків, а й призведе до поглиблення кризи пенсійного забезпечення в майбутньому;

- знизити рівень і тривалість безробіття шляхом реалізації заходів активної політики зайнятості;

- модернізувати ринок праці за рахунок створення умов для збільшення заробітної плати на принципах вартості й ціни робочої сили;

- сформувати ефективну модель зайнятості населення у відповідності до потреб ринку;

- забезпечити зростання мінімальної, номінальної та реальної заробітної плати, бо штучне уповільнення росту зарплати призводить до гальмування національної економіки, спричиняє погіршення умов формування, відтворення та використання трудового потенціалу, збільшує обсяги відрахувань 3 державного бюджету на допомогу та субсидії малозабезпеченим верствам населення;

- встановлювати розмір прожиткового мінімуму не менше від його фактичної величини із врахуванням реальних витрат необхідних для задоволення основних потреб особи кожної соціально-демографічної групи на фізіологічному та соціальному рівнях відповідно конституційного права на достатній життєвий рівень для себе і своєї сім'ї.

Висновки. Підсумовуючи вище зазначене, вважаємо за необхідне активізувати розгляд питань щодо забезпечення соціальної безпеки населення як одного $з$ найважливіших питань національно безпеки та стабільності країни. Комплекс запропонованих заходів дозволить зменшити соціально-економічні ризики, які обумовлені несприятливою демографічною ситуацією, низькою 
якістю національної робочої сили, неефективною зайнятістю населення, існуванням значного неформального сектора економіки, наявністю значної деформації в оплаті праці, що дозволить створити передумови поетапного наближення соціально-економічного стану економіки України до міжнародного рівня, підвищить якість життя їі населення.

\section{Використана література}

1. Аналіз державних стратегічних документів щодо врахування адаптованих для України Цілей Сталого Розвитку до 2030 року : [аналіт. доп.]. Київ: Ін-т сусп.-економ. дослід., 2017. 84 с.

2. Декларація про державний суверенітет України. Відом. Верхов. Ради УРCР. 1996. С. 2.

3. Демографічна ситуація в Україні. Державна служба статистики України : веб-сайт. URL: http://www.ukrstat.gov.ua/.

4. Закон України про основи національної безпеки України : веб-сайт. URL: http://zakon.rada.gov.ua/

5. Заробітна плата: Державна служба статистики України : веб-сайт. URL: http://www.ukrstat.gov.ua/.

6. Конституція України // Відомості Верховної Ради України: веб-сайт. URL: http://zakon.rada.gov.ua.

7. Лібанова Е., Палій О. Ринок праці та соціальний захист: [навч. пос. із соц. політики]. Київ: Основи, 2004. 491 с.

8. Михальченко Г.Г. Сучасні тенденції функціонування ринку праці в умовах загострення соціально-економічної кризи. Адаптивне управління: теорія $i$ практика: Серія «Економіка», 2018. №5(10). URL: https://amtp.org.ua/index.php/journal2/article/view/99/68

9. Новікова О.Ф. Соціальна безпека: організаційно-економічні проблеми і шляхи вирішення. Донецьк: ІЕП НАН України, 1997. 460 с.

10. Отримувачів субсидій меншає, претендентів - більшає : веб-сайт. URL: https://www.bbc.com/ukrainian/news-47666509

11. Офіційний сайт Державного комітету статистики України: веб-сайт. URL: http://www.ukrstat.gov.ua/

12. Показники зайнятості та безробіття населення та їх динаміка в Україні: публікація документів Державної Служби Статистики України URL: https://ukrstat.org/uk/express/expres_u.html/.

13. Прожитковий мінімум (Україна): веб-сайт. URL: http://index.minfin.com.ua/index/wage/.

14. Светлакова А. Демографическая пропасть. Еженедельник 
«Аргументы и Фактыл». 2017. № 1-2 от 18.01.2017.

15. Скорочення субсидій-2020: на що розраховує нова влада : веб-сайт. URL: https://www.slovoidilo.ua/2019/09/24/pogljad/ekonomika/ skorochennyasubsydij-2020-rozraxovuye-nova-vlada.

16. Новікова О.Ф., Сидорчук, О.Г. Стан та перспективи соціальної безпеки в Україні: експертні оцінки: [монографія] / Львівський регіональний інститут ДУ НАДУ; НАН України, Інститут економіки промисловості. Київ; Львів : ЛРІДУ НАДУ, 2018. 184 с.

17. Україна залишається у топ-10 найбідніших країн світу: веб-сайт. URL: https://glavcom.ua/news

18. Шевчук П. І. Соціальна політика. Львів: Світ, 2003. 400 с.

\section{References}

1. Analiz derzhavnykh stratehichnykh dokumentiv shchodo vrakhuvannia adaptovanykh dlia Ukrainy Tsilei Staloho Rozvytku do 2030 roku: [analit. dop.]. Київ: In-t susp.-ekonom. doslid., 2017. 84 s.

2. Deklaratsiia pro derzhavnyi suverenitet Ukrainy. Vidom. Verkhov. Rady URSR. 1996. S. 2.

3. Demohrafichna sytuatsiia v Ukraini. Derzhavna sluzhba statystyky Ukrainy : veb-sait. URL: http://www.ukrstat.gov.ua/.

4. Zakon Ukrainy pro osnovy natsionalnoi bezpeky Ukrainy : veb-sait. URL: http://zakon.rada.gov.ua/

5. Zarobitna plata: Derzhavna sluzhba statystyky Ukrainy : veb-sait. URL: http://www.ukrstat.gov.ua/

6. Konstytutsiia Ukrainy // Vidomosti Verkhovnoi Rady Ukrainy: veb-sait. URL: http://zakon.rada.gov.ua/

7. Libanova E., Palii O. Rynok pratsi ta sotsialnyi zakhyst: [navch. pos. iz sots. polityky], Київ: Osnovy, 2004. 491 s.

8. Mykhalchenko H.H. Suchasni tendentsii funktsionuvannia rynku pratsi v umovakh zahostrennia sotsialno-ekonomichnoi kryzy. Adaptyvne upravlinnia: teoriia $i$ praktyka: Seriia «Ekonomika». 2018. №5(10). URL: https://amtp.org.ua/index.php/journal2/ article/view/99/68

9. Novikova O.F. Sotsialna bezpeka: orhanizatsiino-ekonomichni problemy i shliakhy vyrishennia. Donetsk: IEP NAN Ukrainy, 1997. 460 s.

10. Otrymuvachiv subsydii menshaie, pretendentiv - bilshaie : veb-sait. URL: https://www.bbc.com/ukrainian/news-47666509

11. Ofitsiinyi sait Derzhavnoho komitetu statystyky Ukrainy: veb-sait. URL: http://www.ukrstat.gov.ua/.

12. Pokaznyky zainiatosti ta bezrobittia naselennia ta yikh dynamika $\mathrm{v}$ Ukraini: publykatsiia dokumentiv Derzhavnoi Sluzhby Statystyky Ukrainy URL: https://ukrstat.org/uk/express/expres_u.html/. 
13. Prozhytkovyi minimum (Ukraina): veb-sait. URL: http://index.minfin.com.ua/index/wage.

14. Svetlakova A. Demographic abyss, Weekly «Arguments and Facts», no. 1-2. S. 5-6.

15. Skorochennia subsydii-2020: na shcho rozrakhovuie nova vlada : veb-sait. URL: https://www.slovoidilo.ua/2019/09/24/pogljad/ekonomika/ skorochennyasubsydij-2020-rozraxovuye-nova-vlada.

16. Novikova O.F., Sydorchuk O.H.. Stan ta perspektyvy sotsialnoi bezpeky v Ukraini: ekspertni otsinky: monohrafiia / Lvivskyi rehionalnyi instytut DU NADU; NAN Ukrainy, Instytut ekonomiky promyslovosti. K.; Lviv : LRIDU NADU, 2018. $184 \mathrm{~s}$.

17. Ukraina zalyshaietsia u top-10 naibidnishykh krain svitu: veb-sait. URL: https://glavcom.ua/news.

18. Shevchuk P. I. Sotsialna polityka. Lviv: Svit, 2003. 400 s.

Анна Михальченко,

доктор экономических наук, доцент, заведующая кафедрой экономики

предприятия и менеджмента Учебно-научного профессионально-

педагогического института Украинской инженерно-педагогическаой академии, г. Бахмут, Україна

\section{ОБЕСПЕЧЕНИЕ СОЦИАЛЬНОЙ БЕЗОПАСНОСТИ НАСЕЛЕНИЯ В УСЛОВИЯХ ОБОСТРЕНИЯ СОЦИАЛЬНО ЭКОНОМИЧЕСКИХ РИСКОВ}

Аннотация. В статье доказана необходимость обеспечения социальной безопасности для населения, что является важным фактором социальной стабильности страны и ее национальной безопасности, учитывая усиление социально-экономических рисков, рост социальной напряженности в обществе и неудовлетворительное социально-экономическое развитие страны. Автором охарактеризованы основные социально-экономические риски, с которыми сталкивается население страны в современных условиях и которые приводят к высокой зависимости обеспечения благосостояния значительной части населения от социального обеспечения и социальной защиты.

Целью статьи является исследование современных тенденций социально-экономического состояния страны и определение его особенностей в условиях социально-экономической и политической нестабильности.

Автор проанализировал основные нормативные акты действующего законодательства страны и современные подходы к определению понятия «социальная безопасность», на основании которых и сделан вывод о том, что экономическая составляющая является одной из важных составляющих социальной безопасности. Доказано, что социальная безопасность в 
значительной степени обусловлена экономическими и социальными факторами. Согласно этому охарактеризованы основные демографические, экономические и социальные показатели социально-экономического развития страны; сделан вывод о несоответствии условий социальной безопасности для населения страны, что проявляется в ухудшении демографической ситуации в стране, значительном имущественном расслоении общества, усилении бедности, несоответствия социальных гарантий для обеспечения достойного уровня жизни и т.д. Отмечено, что уровень благосостояния населения остается достаточно низким, исходя из анализа его основных показателей

На основе обозначенных проблем и по результатам проведенного исследования автором обозначены направления обеспечения социальной безопасности населения страны для повышения уровня жизни населения, стимулирования его экономической активности и занятости, что позволит улучшить социально-экономическое положение страны и уменьшить негативные последствия существующих социально-экономических рисков.

Ключевые слова: социальная безопасность, население, социальноэкономические риски, бедность, благосостояние, минимальная заработная плата, прожиточный минимум.

Anna Mykhalchenko,

Doctor of Economic Sciences, Ph.D., Associate Professor, The Head of Department of Economy of Enterprises and Management Educational Scientific Professional Pedagogical Institute of Ukrainian Engineering Pedagogics Academy

\section{PROVIDING OF SOCIAL SAFETY OF POPULATION IN THE CONDITIONS OF INTENSIFYING OF SOCIO-ECONOMIC RISKS}

Abstract. The article proves the need to ensure social security for the population, which is an important factor in the country's social stability and its national security, given the strengthening of socio-economic risks, the growth of social tension in society and the unsatisfactory social and economic development of the country. The author describes the main socio-economic risks faced by the country's population in modern conditions which lead to a high dependence of the welfare of a significant part of the population on social security and social protection.

The aim of the article is to study current trends in the socio-economic state of the country and determine its features in the context of socio-economic and political instability.

The author analyzes the current legislation of the country and the existing approaches to the definition of the concept of "social security" and concludes that the economic component is one of the important components of social 
security.

It has been proven that social security is largely driven by economic and social factors. According to this, the main demographic, economic and social indicators of the socio-economic development of the country are characterized. It was concluded that the conditions of social security for the country's population do not match, which is manifested in a worsening demographic situation in the country, significant stratification of society, increased poverty, inadequate social guarantees to ensure a decent standard of living, etc. It is noted that the level of well-being of the population remains extremely low, based on an analysis of its main indicators.

Based on the identified problems and the results of the study, the author outlines the directions for ensuring the social security of the country's population to increase the standard of living of the population, stimulate its economic activity and employment, which will improve the country's socio-economic situation and reduce the negative consequences of existing socio-economic risks.

Keywords: social security, population, socio-economic risks, poverty, welfare, minimum wage, cost of living. 